\title{
Sebészi megoldások krónikus multivisceralis artériás elzáródások esetében
}

\section{Surgical solutions in multivisceral arterial occlusions}

\author{
DZSINICH CSABA ${ }^{1, @}$, BARTA LÁSZLÓ ${ }^{1}$, BOGDÁNY KLAUDIA $^{1}$, TÓTH TAMÁS ${ }^{1}$, \\ PATAKI TIBOR ${ }^{2}$, NAGY GABRIELLA ${ }^{2}$ \\ ${ }^{1}$ Magyar Honvédség Egészségügyi Központ, Szív-Ér-Mellkas Sebészet \\ (mb. osztályvezető: dr. Darabos Gábor) \\ ${ }^{2}$ Magyar Honvédség Egészségügyi Központ, Aneszteziológiai és Intenzív Terápiás Osztály \\ (osztályvezető: dr. Csomós Ákos PhD)
}

\begin{abstract}
Bevezetés: A zsigeri artériák akut elzáródása fulmináns klinikai képpel társul, és az esetek jelentős százalékában gyorsan halálhoz vezet. Ha ezen artériák obliteratív folyamata lassan alakul ki, a zsigeri artériák gazdag kollaterális kapacitása a klinikai tüneteket sokáig elfedi. Az esetek egy részében az anatómiailag közel fekvő renalis artériák obliteratív folyamata, illetve a társuló aortoiliacalis szűkületek és/vagy elzáródások rendkívül szerteágazó klinikai képet okozhatnak. Az átfedések más hasi betegségekkel félrevezetők lehetnek, emiatt késedelmes felismerésük súlyos következményekkel járhat. Előfordulásuk nem gyakori, ismeretük azonban nélkülözhetetlen mind a diagnosztika, mind a megoldás szempontjából. Dolgozatunkban e bonyolult kórkép eseteit tárgyaljuk, és ismertetjük a megoldások lehetőségeit.
\end{abstract}

Kulcsszavak: krónikus multivisceralis artériás elzáródások, malabsorptio, diagnózis, megoldási lehetőségek

Introduction: Acute occlusions of the visceral arteries result in fulminant clinical consequences and without fast and appropriate treatment may lead to fatal outcome. If the obliterative disease has slow progression the huge capacity of the collateral circulation of the visceral arteries may remain free of symptoms at long run. By progression of the obliterative disease and extension to both, the renal arteries and the aortoiliac segment the clinical picture becomes more colourful. Symptoms mimicking other abdominal disorders may easily lead to misdiagnosis and/or unnecessary delay of adequate treatment - finally to organ or life threatening condition. In the present paper we deal with this infrequent, but severe disease in order to recognize it in time, to recommend proper diagnostic workup and propose adequate treatment.

Keywords: chronic multivisceral arterial occlusions, malabsorption, diagnostic workup, treatment options

Beérkezett: 2021. április 30.; elfogadva: 2021. május 31.

\section{Bevezetés}

A zsigeri artériák krónikus obliteratív megbetegedései több morfológiai változatban jelennek meg, igen változatos klinikai képet okozva. Meglehetősen ritka előfordulásuk, alattomosan progrediáló jellegük az érelzáródások kombinációitól függően a gazdag kollaterális keringés kifejlödése révén sokáig tünetmentesek maradhatnak. A klinikai tünetek gyakorta utánozzák vagy átfedik más, gyakrabban előforduló hasi betegségek tüneteit. Klinikai diagnózisuk ezért gyakran késedelmes, bizonytalan. Elörehaladott stá- diumban felszívódási zavar laboratóriumi tünetei kelthetik az alapos gyanút. Más területeken jelentkező obliteratív arteriopátiák terelhetik figyelmünket e klinikai entitás felé. Anamnesis felvétele, majd fizikális vizsgálat során a zsigeri erek vetületében hallható érzörej megjelenése, posztprandiális fájdalom, később testsúlyvesztés, majd marasmus kialakulása indokolja a differenciál diagnosztikai vizsgálatok kiterjesztését. Az artéria renalisokat, illetve az aortoiliacalis területet is érintő obliteratív folyamatok tovább színesítik a klinikai képet, de egyúttal korábban terelhetik figyelmünket

\footnotetext{
@ Levelezési cím/Corr. address: Prof. dr. Dzsinich Csaba, Honvéd Egészségügyi Központ, Szív-Ér-Mellkas Sebészeti Osztály, 1134 Budapest, Róbert Károly krt. 44., Tel.: +36 3093189 06, E-mail: csaba@dzsinich.com
} 
a multivisceralis érelzáródások irányába. A modern képalkotó eljárások, a két irányból végzett DSA, vagy a manapság előnyben részesített CTA, MRA a diagnózist jelentősen megkönnyítették. Míg a sztenotizáló folyamatok jelentős része endovasculáris technikákkal megoldható, teljes elzáródások e vonzó, kisebb sebészi megterhelést jelentő eljárásokkal nem minden esetben állíthatók helyre. Jelen munkánkban azokat a nyitott sebészi megoldásokat mutatjuk be néhány esetünk kapcsán, amelyeket e bonyolult betegcsoport kezelése során alkalmaztunk.

\section{Betegismertetés}

1. beteg: 45 éves dohányzó férfi betegnél hasi panaszok, 6 hónap alatt mintegy $8 \mathrm{~kg}$ fogyás miatt történt kivizsgálás. Gasztroenterológiai betegséget nem találtak. Fizikális vizsgálata során a hasi erek vetületében észlelt szisztolés érzörej alapján került sor DSA elvégzésére, amely mind a Truncus coeliacus (TC), mind az a. mesenterica superior (AMS) elzáródását igazolta. A zsigerek vérellátását az a. mesenterica inferioron (AMI) át hatalmasan tágult Riolan árkád biztosította (1. ábra).

Mütéti megoldásként felső median laparotómián át a TC helyreállítását venás interpositummal oldottuk meg. Zavartalan postoperatív szak után a beteg panaszmentessé vált. Kétéves utánkövetés során testsúlya gyarapodott, hasi panaszai megszüntek.

2. beteg: 25 éves sovány, erősen dohányzó fiatal férfi hármas antihypertenzív gyógyszeres kezeléssel sem beállítható 180/110 Hgmm vérnyomással került kivizsgálásra renovascularis hypertonia alapos gyanújával. Globális vesemüködése enyhe proteinurián kívül eltérést nem mutatott. Egyéb
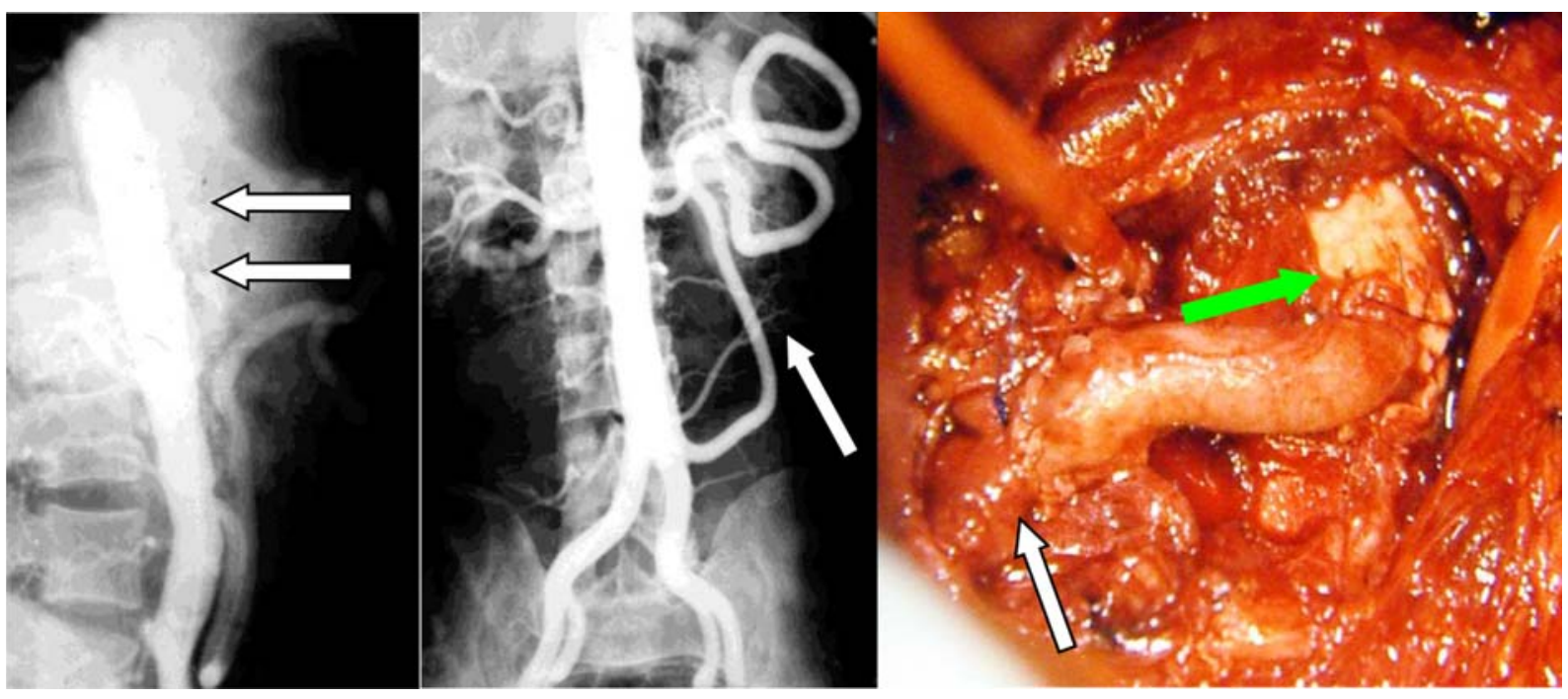

1. ábra. Első betegünk DSA képei és a truncus coeliacus helyreállítása, amit aorto-coeliacalis venás interpositummal végeztünk. A jó kollaterális keringés nem tette szükségessé az SMA helyreállítását is
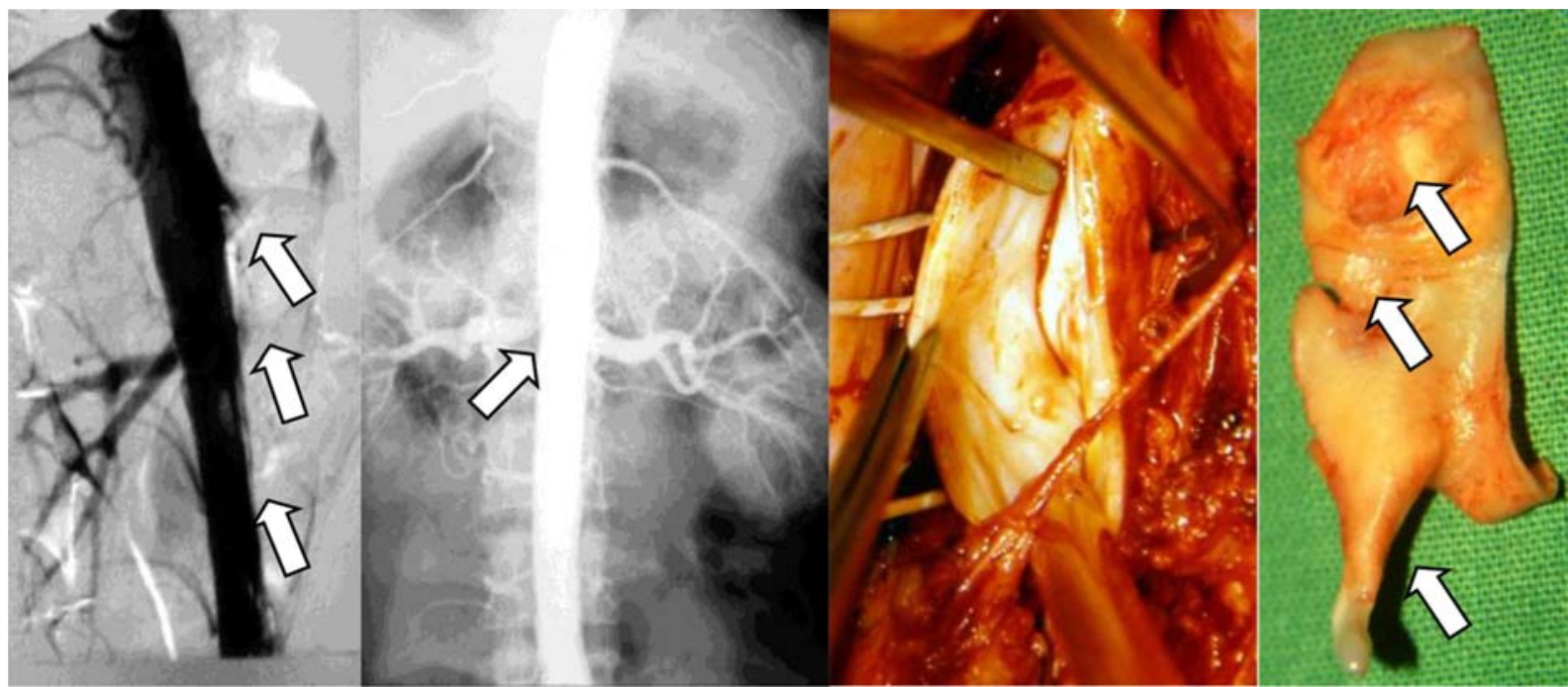

2. ábra. Második betegünk angiogramja. A nyilak az occludált TC, SMA és IMA, valamint a stenoticus jobb a. renalist jelölik. Intraoperatív kép és a specimen látható 


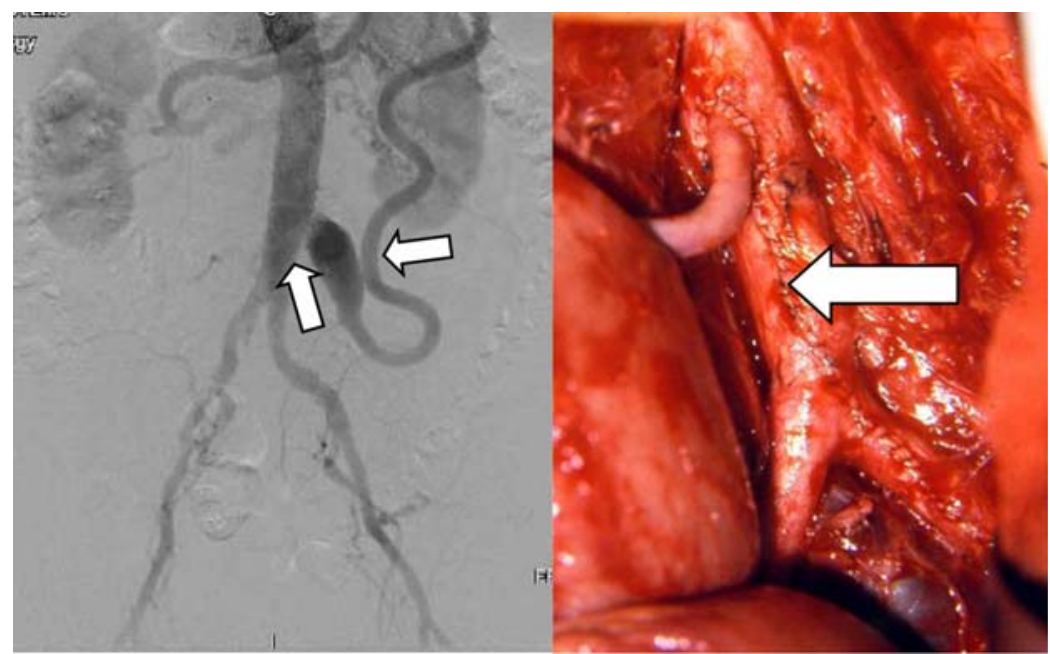

3. ábra. A harmadik beteg angiogramján jól látható a tágult arcus Riolani és a stenoticus IMA poststenoticus tágulattal. Kombinált beavatkozásként aorto-biiliacalis endarteriektomiát, és az IMA helyreállítását venás interpositummal végeztük

laboratóriumi eredményei a normál értékhatárokon belül voltak. Hasi panaszokat nem említett. Fizikális vizsgálata során a sovány betegen a jobb vese artéria vetületében holoszisztolés zörej volt hallható. Végtagjain pulzus státusza rendben volt. DSA angiogrammokon a jobb renalis eredési szükülete és poststenoticus tágulata mellett meglepetésre mindhárom zsigeri artéria szájadékának eredési elzáródását észleltük. Jobb ferde fekvésben végzett thoracoabdominalis, transdiaphragmaticus, retroperitonealis feltárásból végeztünk aortakirekesztést teljes heparinisatióban. Az aorta megnyitása után vaskos, vizenyős, cholesteroticus, nem calcificalt intima lemezt találtunk. Localis desobliteratiót végeztünk. Mind a TC, SMA és jobb a. renalis szájadékból kiemeltük az obturáló tölcsért, majd az aortában az intima distalis szélének rögzítése után az aortát kettős tovafu- tó varrattal zártuk (2. ábra). Vizeletelválasztása az aortakirekesztés megszüntetése után azonnal megindult. Az alvadásgátlás felfüggesztését, revisio és drainek bevezetését követően rekonstruáltuk a tapadása mentén leválasztott rekeszizmot, és a sebet rétegei szerint zártuk. A postoperatív szak eseménytelen volt. Vérnyomása gyorsan rendeződött. Gyógyult sebbel a 7. napon bocsátottuk el. Ellenörzésre rendszertelenül jelentkezett, de 5 év után is panaszmentes volt, enyhe antihypertenzív medicatio és TAG kezelés mellett.

3. beteg. 54 éves dohányzó nőbeteg hasi panaszok nélkül „magas” dysbasia miatt került kivizsgálásra. DSA aortografia a TC, SMA elzáródását, és az IMA szájadékának szűkületét és jelentős fusiformis poststenoticus tágulatot

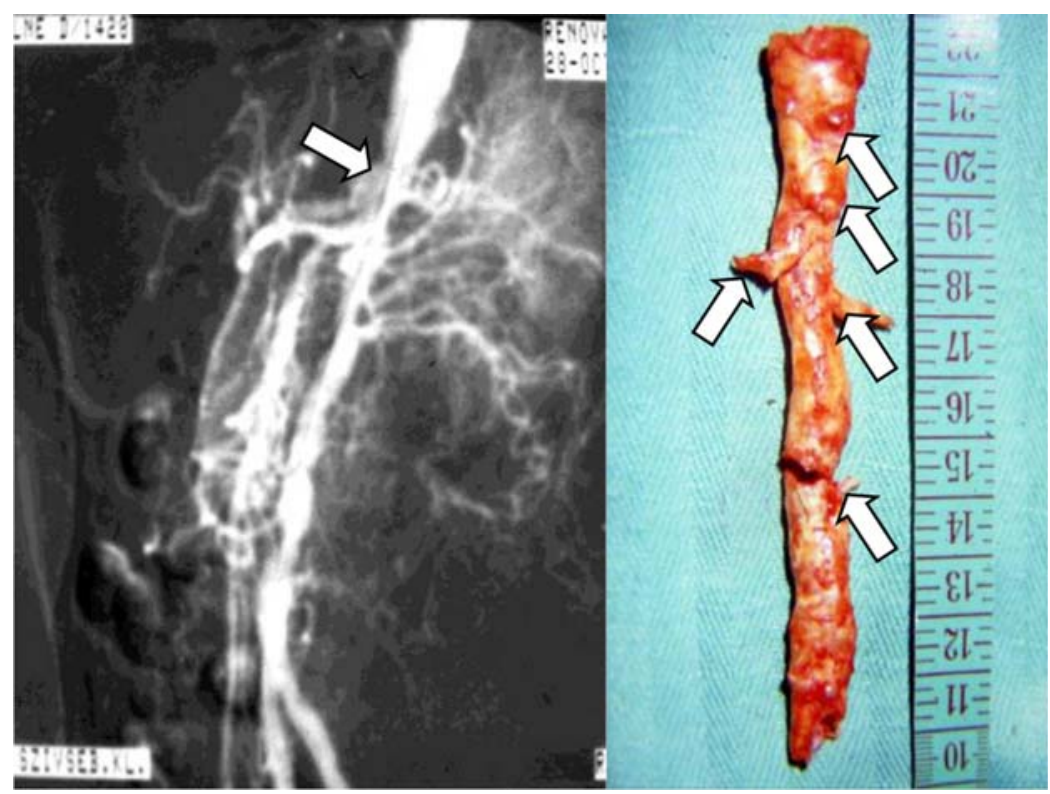

4. ábra. Negyedik betegünk DSA képe az aorta abdominalis és mellékágai előrehaladott arteriosclerosisát mutatja. A mütét során eltávolított, a lument öntvényszerüen kitöltő speciment mutatjuk, amelyen a szájadékokból kiemelt nyilakkal jelzett stenotizáló plakkok jól felismerhetők 
mutatott, amit instabil elváltozásnak tartottunk. Az aorta distalis szakasza és mindkét iliaca communis meszes szűkületei igazolódtak. Középső és alsó median feltárás után alvadásgátlásban kirekesztettük a subrenalis aortát mindkét a. iliaca communis oszlásáig, és az aortán és a bal a. iliaca communison nyitott, a jobb oldalon félig nyitott desobliteratiót végeztünk, majd resecaltuk az IMA aneurysmát, és kontinuitását venás interpositummal oldottuk meg (3. ábra). Zavartalan gyógyulás után a beteg egy év múlva is panaszmentes volt, majd későbbi ellenőrzésre nem jelentkezett. Tartós TAG kezelést kapott.

4. beteg. 67 éves, 50 éve dohányzó sovány nőbeteg, folyamatos lassú, mintegy 10 kg-os fogyás, romló járóképesség és nehezen beállítható hypertonia miatt került kivizsgálásra. Veseműködésének beszükülése, proteinhiány és enyhe anaemia laboratóriumi jeleit mutattuk ki. Postprandialis panaszai jelentéktelenek voltak. Fizikális vizsgálata során a hasi erek vetületében észlelhető szisztolés zörejt, és gyengültebb femoralis pulsusokat találtunk. DSA angiográfia az aorta súlyos meszesedését igazolta a rekesz szintjétől az aorta bifurcatióig. Súlyos szklerotikus szükületeket mutattunk ki a TC, SMA, IMA és mindkét a. renalis szájadékában. Teljes median laparotómia, és heparinisatio után az aortát supravisceralis szakaszától mindkét iliaca communisig terjedően kirekesztettük, és oldalágait aláhurkoltuk. A kirekesztett aortaszakasz hosszanti megnyitása után az obturáló, öntvényszerü mészhengert a szájadékokba terjedő kalcifikált tölcsérekkel együtt egyben kiemeltük (4. ábra). A szájadékok szondázása és átöblítése, és debridement után az aortát kettős tovafutó varrattal zártuk, és a keringést lassan felengedtük. A Heparin felfüggesztését követően a hasüreget átvizsgáltuk, és a sebet zártuk. A beteg 5 éven át állt éves ellenőrzés alatt. Kondíciója, járóképessége jelentősen javult, minimális antihypertenzív kezelést igényelt. Vesemüködése enyhén beszükült, stabil értékeket mutatott, dialízist nem igényelt.

5. beteg: 34 éves erősen leromlott állapotú, láncdohányos nőbeteg 2 nap óta anuriával, állandó heves hasi fájdalmakkal exsiccalt, cachectizált állapotban marmorizált, hideg alsó végtagokkal más kórházból került átvételre (5. ábra).

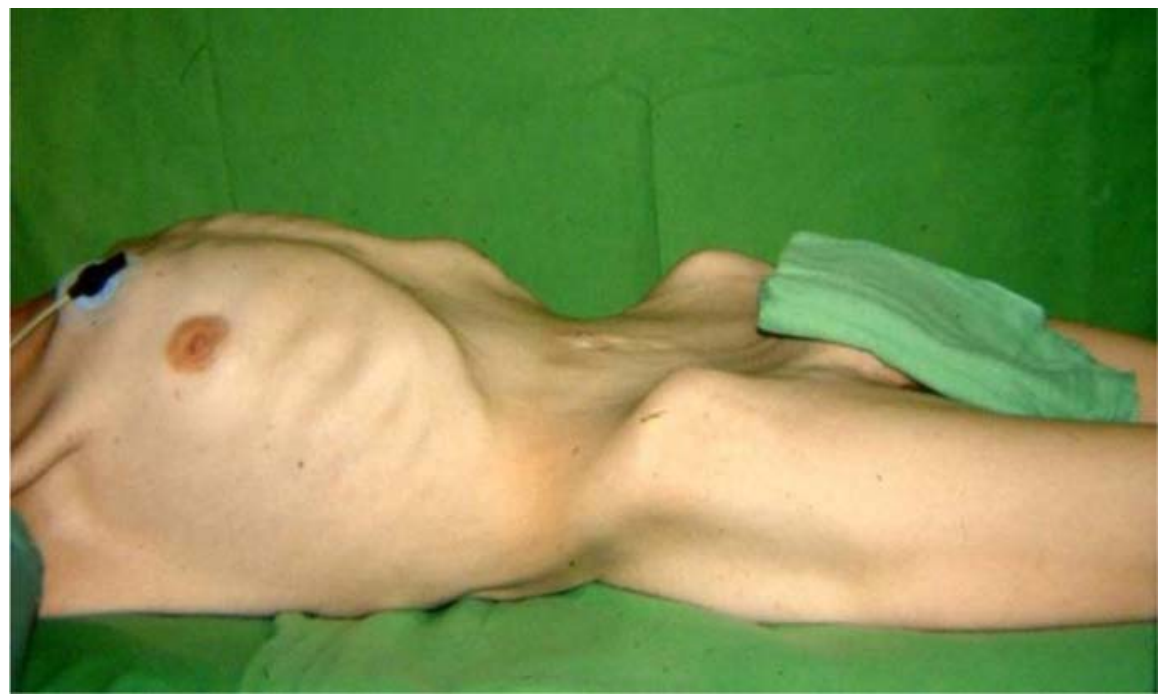

5. ábra. Ötödik betegünk krónikus zsigeri keringési zavar okozta leromlott állapota, ami súlyos heveny renalis, visceralis és alsó végtagi keringésromlással társult

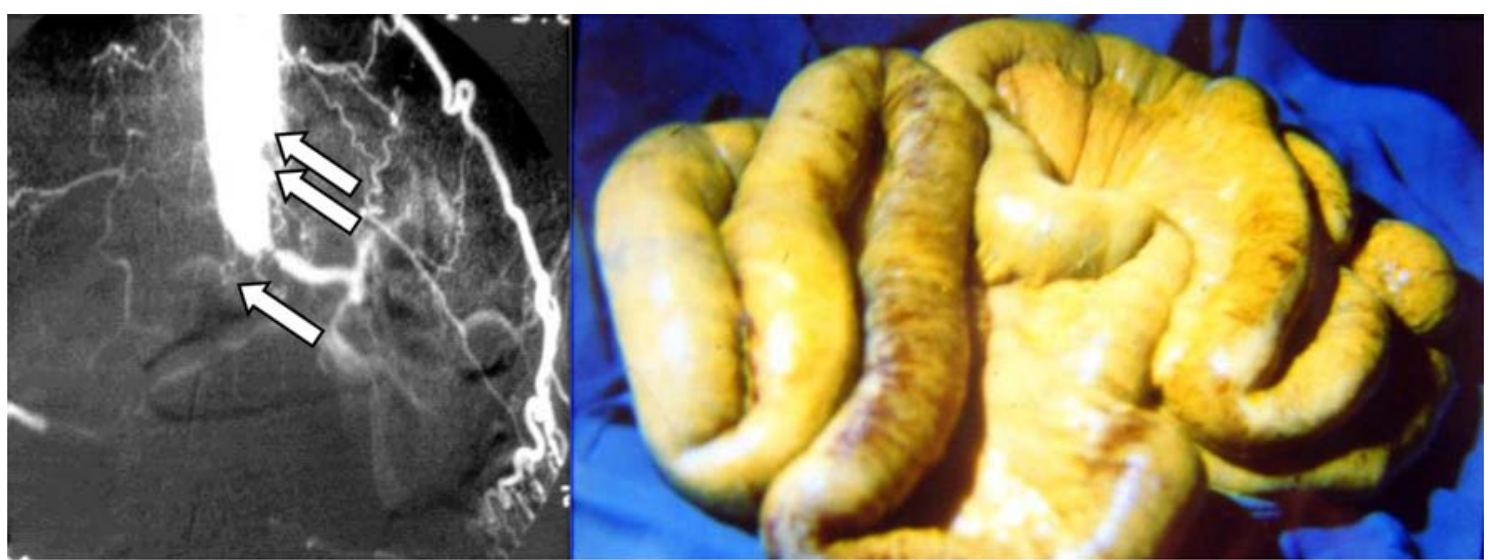

6. ábra. Az ötödik beteg angiogramja, és a feltárás során észlelt foltosan ischemiás vékonybelek 

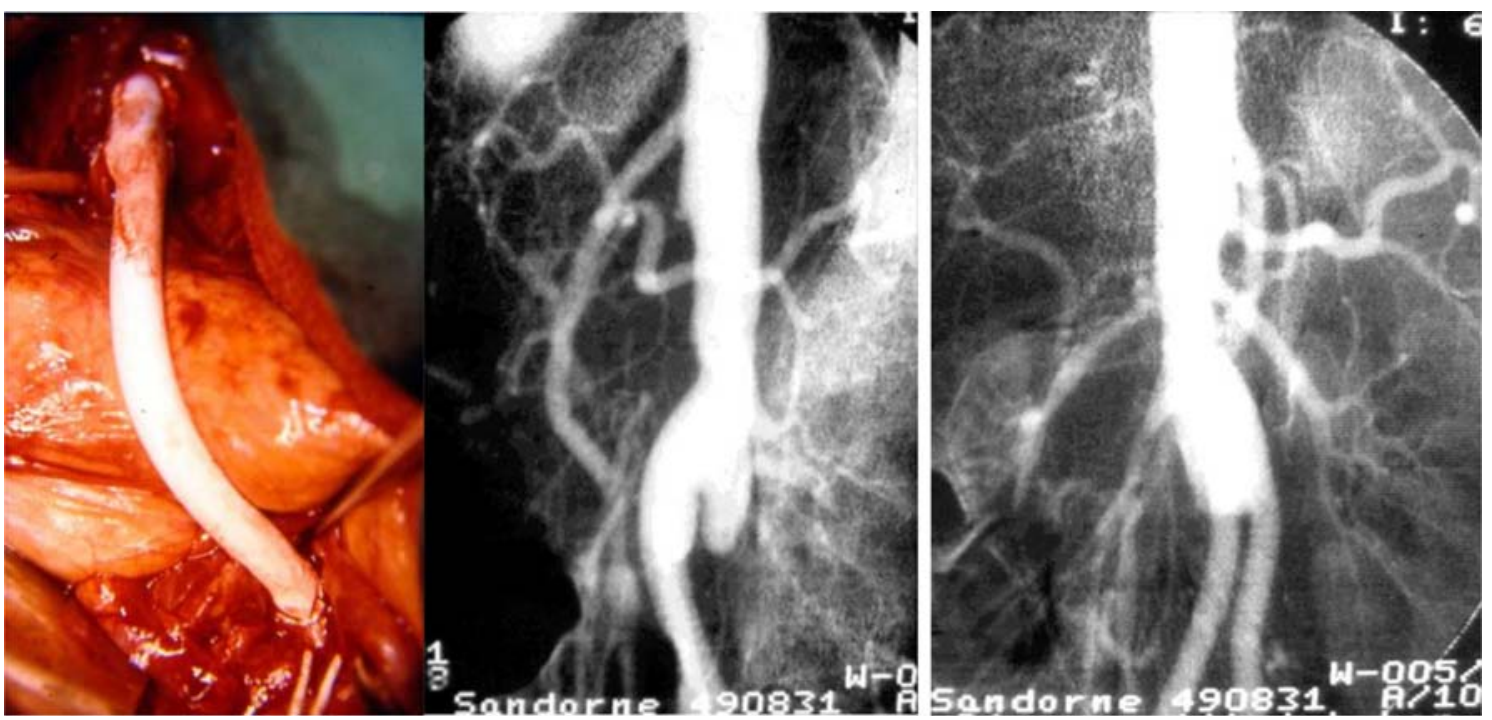

7. ábra. Az ötödik beteg aorto-mesenterialis antepancreaticus bypass mütéti fotója, és a bonyolult rekonstrukció kétirányú kontroll DSA képei

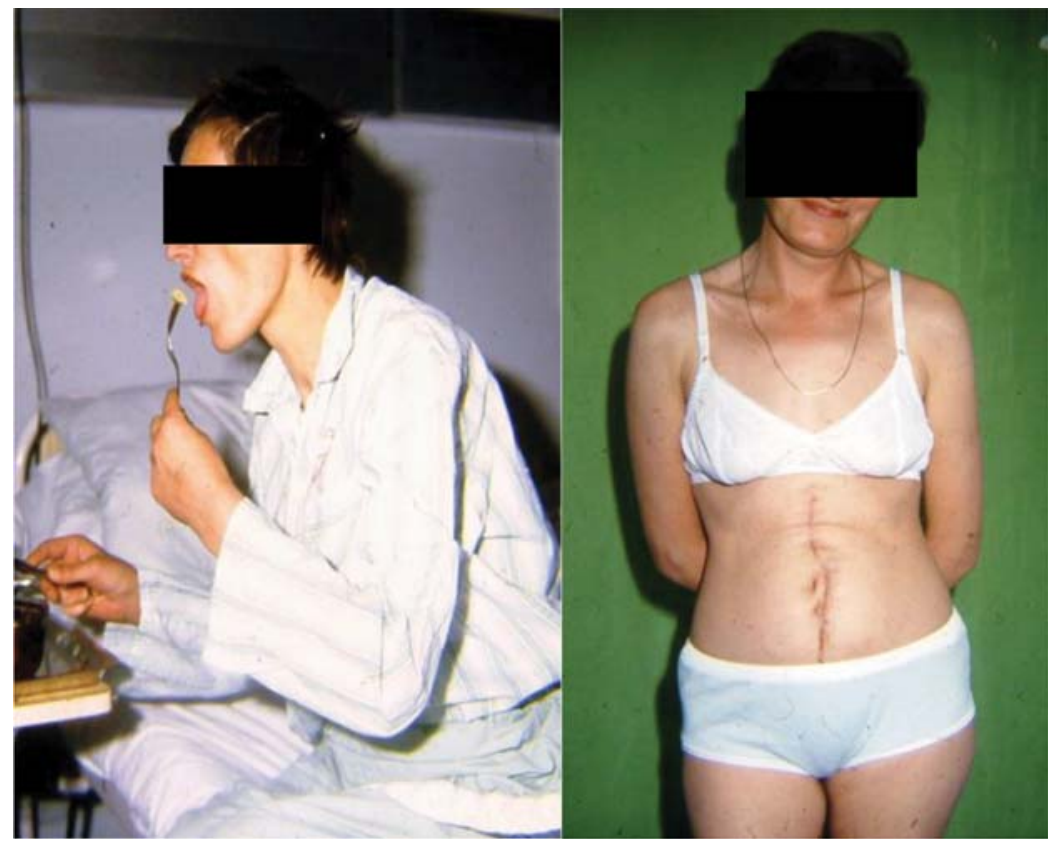

8. ábra. Ötödik betegünk 3 nappal a kiterjedt mütét után végre panaszmentesen tudott étkezni. Az egy év múlva készített kép a beteg jelentősen javult állapotát mutatja

Laboratóriumi vizsgálatai jelentős leukocytosist, mérsékelt anaemiát, hypoproteinaemiát, jelentősen emelkedett kreatinin értéket igazoltak. Emelkedett $\mathrm{K}+$, normál máj- és pankreasenzimeket észleltünk. Anamnézisében jelentősen beszükült járóképesség, $50 \mathrm{~m}$ alatti magas, farizomzatban is jelentkező dysbasia, állandó postprandialis fájdalom miatt napok óta táplálék- és folyadékbevitelre képtelen beteg azonnali angiographiára került. A DSA a TC, SMA, jobb a. renalis és a hasi aorta subrenalis szakaszának elzáródását, a bal a. renalis subtotalis szükületét és a krónikus folyamat jeleként tágult kollaterális artériákat mutatott. Azonnal mütétet végeztünk. Teljes median laparotómia után sápadt, foltosan ischemiás beleket észleltünk (6. ábra). A ligamentum arcuatum átvágása után feltártuk a mellkasi aorta distalis szakaszát, és az occludált TC eredését annak oszlásáig, a tripus Halleriig. Infracolicusan közelítettük meg a visceralis aorta segmentumot annak ágaival együtt. A mesenterium gyökben felkerestük az SMA nyitott II. szakaszát, majd feltártuk mindkét femoralis villát. Heparinisatióban első lépésként a distalis mellkasi aortát rekesztettük ki, és arról arteriotomiát vezettünk a TC oszlásáig. Az így megnyitott TC localis endarteriektomiája után $6 \mathrm{~mm}$-es Gore grafttal az aortoarteriotomiáról ferde anastomosissal bypasst indítottunk antepankreaticus graft vezetéssel az SMA nyitott szakaszáig, amellyel elkészítettük a distalis ferde anastomosist. A keringés e szakaszának felengedése után az addig 
foltosan sápadt, ,patchy” vékonybelek pár perc után élénk rózsaszínűvé váltak. A kirekesztést a TC alá áthelyezve ismét aortotomiát végeztünk a visceralis aortáról a subrenalis szakaszra terjedően. Ezután localis endarteriektomia útján mindkét renalis szájadékot szabaddá tettük, és a veséket hütött Ringer lactattal átöblítettük. Az aortotomia interrenalis, proximalis szakaszának zárása után a kirekesztést subrenalisan helyeztük fel, és megindítottuk a renalis keringést. A vizeletelválasztás szinte azonnal megindult. Az aortomia distalis szakaszáról indított $14 \times 7 \times 7$ bifurcatiós Dacron grafttal 1.a. aortobifemoralis bypasszal fejeztük be a rekonstrukciót. A sebeket l.a zártuk (7. ábra). A beteg másnap felkelt, és végre hasi görcsök nélkül táplálkozni tudott. Állapota gyorsan, folyamatosan javult, és az addig munkaképtelen beteg egy év múlva jó általános állapotban stabil munkaviszonyban dolgozott (8. ábra).

\section{Megbeszélés}

A zsigeri szervek artériás vérellátását a truncus coeliacus, az a. mesenterica superior és inferior, valamint az utóbbi a. colica sinistrával összeköttetésben álló a. iliaca interna visszahajló ágával, az a. rectalis superiorral együtt szolgáltatják. Ezen artériák anatómiailag preformált kollaterális hálózattal képesek messzemenően kompenzálni bármelyik ág elzáródását (1. táblázat, 9. ábra). Ezek a kollaterális utak ritkán természetes folyamatok, gyakrabban sebészi beavatkozások, gyomor és bélreszekciók következtében megszakadhatnak. Az elégtelen kollaterális keringés hamarabb vezet klinikai tünetek megjelenéséhez.

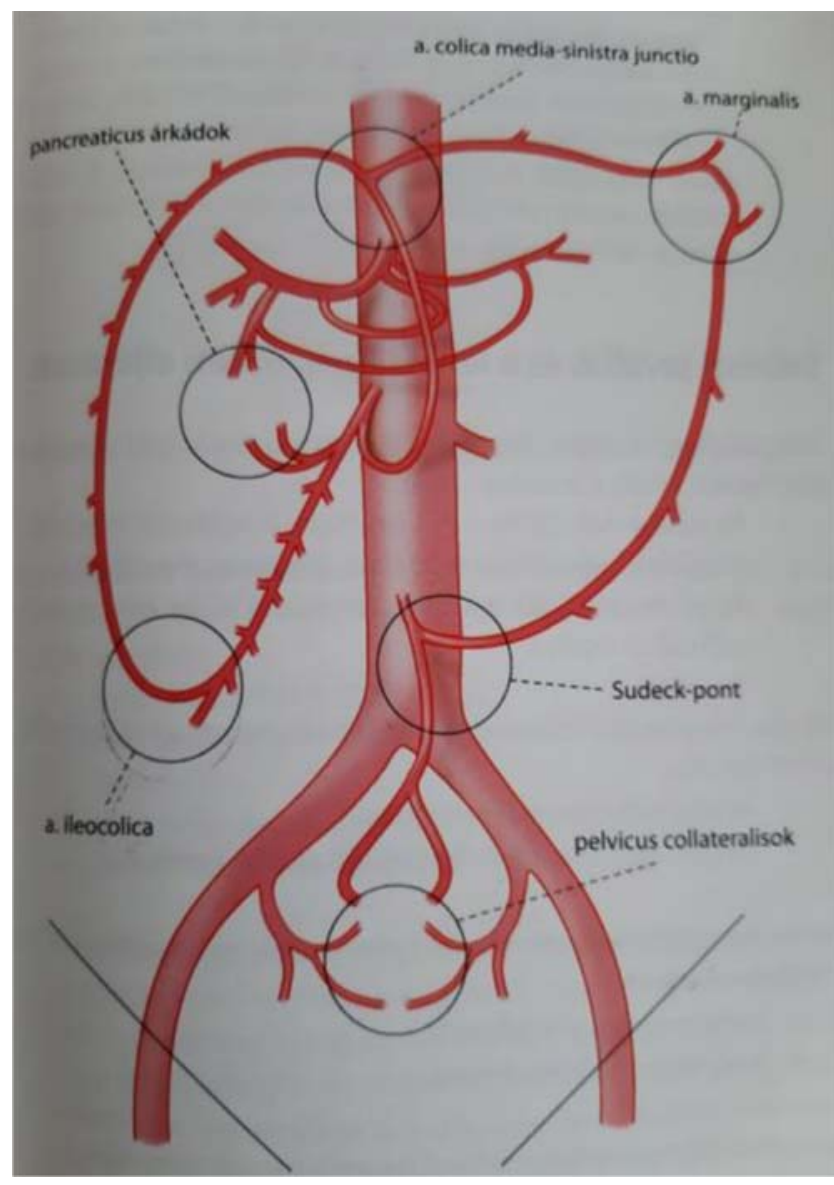

9. ábra. A gasztrointesztinális rendszer artériás vérellátásának sémás rajza. A karikával jelölt szakaszok a kollaterális összeköttetéseket jelölik

1. táblázat. A zsigeri artériák kollaterális összeköttetései

\begin{tabular}{lll}
\hline Truncus coeliacus & A. mesenterica sup. & A. mesenterica inf. \\
\hline a. hepatica comm. & a. colica media & a. marginalis Drummond \\
a. gastroduod & a. pancreaticoduod. inf. & a. colica sinistra \\
a. pancreatioduod. sup. & & Sudeck pont \\
& a. rectalis sup. \\
& a. iliaca interna \\
& a. iliaca communis \\
& a. iliaca externa \\
\hline
\end{tabular}

2. táblázat. A zsigeri artériák krónikus elzáródásának klinikai stádiumai

\begin{tabular}{clll}
\hline \multicolumn{1}{c}{ I } & \multicolumn{1}{c}{ II } & \multicolumn{1}{c}{ III } & \multicolumn{1}{c}{ IV } \\
\hline Tünetmentes & Enyhe hasi görcs & Súlyos hasi görcsök & Éhomri hasi görcsök \\
& & Fogyás & Adynamia \\
& & Psyosis \\
& & Kachexia \\
& & Halál \\
\hline
\end{tabular}


A zsigeri ágak közötti kollaterális lehetőségek szinte zavartalanul képesek ellátni az érintett szervek nyugalmi és postprandialis átáramlási igényét, ha csupán egy ág szájadékánál alakul ki az elzáródás, és nem érinti a belöle kiinduló, illetve a fogadó kollaterális ágak szájadékait. Kivételt képez a truncus coeliacus compressziós szindróma, amely önmagában is tünetképzö lehet ${ }^{1}$. Amennyiben a kollaterális keringés korábbi sebészi megszakítás vagy az obliteratív betegség miatt károsodik, előbb-utóbb klinikai tünetek és a felszivódási zavar klinikai és laboratóriumi jelei mutatkozhatnak. A zsigeri artériák elzáródását és annak következményeit lovakon Baumgartner figyelte meg elsöként 1864-ben. Humán klinikai észlelés első leírása 1901böl Oertner és Schwartz nevéhez füződik. Kachexiában szenvedö betegük kiterjedt hasi érzörejei alapján gondoltak multivisceralis érelzáródásra, amit boncolási lelet igazolt. Krónikus zsigeri keringési zavar tünetei egyes esetekben sokáig némák maradhatnak a már jelzett gazdag kollaterális keringés következtében ${ }^{2}$. A klinikai tünetek megjelenése számos más, hasi szervet érintő, gyakoribb betegségre jellemző tüneteket utánozhat. Gyomor- és nyombélfekély, epeút betegségek, krónikus pankreatitis, vékony- és vastagbélgyulladásos betegségek, összenövések, vesekövesség stb. okozhatnak hasonló tüneteket. A kiterjedt differenciáldiagnosztikai vizsgálatok elősegítik az egyéb betegségek felismerését vagy kizárását. Elörehaladott krónikus visceralis artériás occlusio markáns tünetei figyelmünket egyre inkább a malperfusio irányába terelik. Az étkezés által kiváltott fájdalom súlyos psychoticus tünetekkel járhat, amit akár egy korty vízivástól való félelem is előidézhet (2. táblázat). A laboratóriumi eredmények a felszívódási zavar okozta fehérje-, vitamin-, ion- és vashiány jellemzőit mutatják, nem tekinthetők specifikusnak (3. táblázat). Az anamnézis és a fizikális vizsgálat jelentősen elösegíti e ritka, esetenként súlyos veszélyeket rejtő kórforma felismerését. A pontos diagnózist a modern képalkotó eljárások biztosítják. Korábban a DSA volt a diagnózis alapja, ami azonban csak kétirányú felvétellel képes igazolni a zsigeri artériák orificialis elzáródását. Értékes indirekt jelként a hatalmasan tágult kollaterális ágak adhatnak iránymutatást. Az ujjnyira tágult, kanyargós Riolan árkád - a Conolly jel diagnosztikus értékkel bír. A 3D CTA, illetve MRA a diagnózis további értékes, korszerü eleme. Az ultrahang-diagnosztika is jelentősen hozzájárulhat a zsigeri keringészavar felismeréséhez (4. táblázat) ${ }^{3,4}$. Indirekt vizsgálati lehetőség volt korábban a krónikus zsigeri hypoperfusio kimutatá-

3. táblázat. A zsigeri artériák elzáródásának laboratóriumi következményei

\begin{tabular}{llll}
\hline Proteinhiány & Vashiány & Hypovitaminosis & Hypoionia \\
\hline oedema & anaemia & hiánytünetek & adynamia \\
\hline
\end{tabular}

4. táblázat. Képalkotó vizsgálatok DSA, CTA, MRA. A zsigeri ágak krónikus elváltozásának variációi

\begin{tabular}{ll}
\hline Zsigeri artériák obliteratív folyamata & Multiplex zsigeri elzáródások változatai \\
\hline Szükület & Truncus coeliacus + a. mesenterica sup. \\
Elzáródás & a. mesenterica sup. + a. mesenterica inf. \\
Kollateralizált & TC + AMS + AMI \\
Nem kollateralizált & TC + AMS + AMI + a. renalis/ok \\
Monoarterialis & TC + AMS + AMI + AR + aortoiliacalis \\
Multiplex & \\
\hline
\end{tabular}

Rövidítések: TC - truncus coeliacus; AMS - arteria mesenterica superior; AMI - arteria mesenterica inferior; $\mathrm{AR}$ - a. renalis

5. táblázat. A zsigeri artériák krónikus elzáródásának fizikális tünetei
a. fogyás különböző stádiumai
b. szisztolés érzörej a hasi artériák vetületében (hiánya nem kizáró tényező)
c. egyéb érterületek felett hallható érzörej kiterjedt obliteratív érbetegségben
d. más érterületen észlelt artériás elzáródás
e. hasi panaszok, malabsorptio és hypertonia egyidejü észlelése
f. hasi panaszok, hypertonia és dysbasia, vagy más érterület érintettsége 
sára a 24 órás tonometria ${ }^{5}$. Jó kollaterális keringés mellett akár egyetlen nyitott zsigeri artéria is panaszmentes állapotot képes fenntartani, ezért a súlyos obliteratív folyamatra néha csak mellékleletként derül fény, mint azt eseteink is bizonyítják. Ha azonban az egyetlen nyitott artérián instabil állapotot okozó stenotizáló folyamat zajlik, preventív beavatkozás szükséges. Panaszokat okozó állapotban a zsigeri keringés helyreállítása halaszthatatlan ${ }^{6,7}$. A zsigeri erek feltárása lehet thoracoabdominalis, retroperitonealis és transabdominalis feltárás, laparotómia és retroperitonealis behatolás útján. Rekonstruktív megoldások, mint endarteriektomia, anterograd versus retrograd bypass technikák, illetve replantációk végezhetö ${ }^{8}$. Amennyiben az erek közötti kollaterális keringés megtartott, akár egy zsigeri artéria helyreállítása is megszüntetheti a beteg panaszait ${ }^{9}$. Ha a zsigeri artériák megbetegedése az anatómiailag közel fekvő renalis artériák szükületével, esetleg aortoiliacalis obliteratív folyamattal is társul, a klinikai kép rendkívül szerteágazóvá válik, és komplex beavatkozás indokolt (5. táblázat). Az utóbbi évek technikai haladása az endovascularis, katétertechnikai beavatkozások elöretörését eredményezték. A tuncus coeliacus kompressziós szindróma esetén is végeznek ballon katéteres tágítást stent behelyezéssel. A tágítás a sokszor erőteljes, tendinosus ligamentum arcuatum miatt okoz technikai nehézséget, máskor a hypoplasticus, vékonyfalú truncus tágítása jelent veszélyt - föként ha poststenoticus tágulattal jár. Hibrid megoldásként a ligamentum laparoszkópos átvágása és a ballonos tágítás kombinációja jelenthet megoldást ${ }^{10}$. A hasi aorta zsigeri szegmentumának vaskos kalcifikációja, a zsigeri ágak komplett obliteratiója és renalis ágak súlyos szűkülete/elzáródása thoracoabdominalis endoartectomiát, és a szájadékokat elzáró mésztölcsérek eversióját tehetik szükségessé. Kiterjedt folyamat egyidejűn aortoilicalis helyreállitást is indokolhat. Bár e kombinált mütétek ritkán kerülnek sorra, és jelentős sebészi terheléssel járnak, de jó korai és tartós eredménnyel végezhetök ${ }^{11-14}$.

$\mathrm{Az}$ a. mesenterica superior anatómiája, elhelyezkedése előnyösebb helyzetet kínál az endovascularis beavatkozásra. Az orificium közeli rövid szakaszú stenosisok megoldása jó eredménnyel kecsegtet, amit az intramuralis körkörös kalcifikáció, „,coral reef” jelentősen ronthat ${ }^{15,16}$. A meszes plakk dissectiója, illetve a stent behelyezése során a kollaterális keringés szempontjából igen fontos a. colica media, vagy a. pancreaticoduodenalis inferior szájadékának lefedése komoly szövődmény forrása lehet. Az a. mesenterica inferior szájadékának tágítása is jelentősen javíthatja a zsigeri keringést, de gondosan kerülni kell a Sudeck pont sérülését. Poststenoticus aneurysma esetében a sebészi reconstructio - graft interpositio - nagyobb biztonságot jelenthet. $\mathrm{Az}$ endovascularis beavatkozások alacsonyabb kockázattal hasonló technikai sikerrátával járnak, mint a sebészi megoldások, de a hosszú távú eredmények attól jelentősen elmaradnak $^{17-20}$.

A sebészi megoldások a komplex elváltozásokban mint azt eseteink igazolják - az endovascularis megoldások térhódítása ellenére sem nélkülözhetők.

\section{Irodalomjegyzék}

${ }^{1}$ Dunbar JD, Molnar W, Beman FF, Marable SA: Compression of the celiac trunk and abdominal angina. Am J Roentgenol Radium Ther Nucl Med 1965; 95(3): 731744.

${ }^{2}$ Fisher DF Jr, Fry WJ: Collateral mesenteric circulation. Surg Gynecol Obstet 1987; 164(5): 487-492.

${ }^{3}$ Cognet F, Ben Salem D, Dranssart M, Cercueil J-P, Weiller M, Tatou E, Boyer L, Krausé D: Chronic mesenteric ischemia: imaging and percutaneous treatment. Radiographics 2002; 22(4): 863-879.

${ }^{4}$ Armstrong PA: Visceral duplex scanning: evaluation before and after artery intervention for chronic mesenteric ischemia. Perspect Vasc Surg Endovasc Ther 2007; 19(4): 386-392.

${ }^{5}$ Mensink PB, Geelkerken RH, Huisman AB, Kuipers EJ, Kolkman JJ: Twenty-four hour tonometry in patients suspected of chronic gastrointestinal ischemia. Dig Dis Sci 2008; 53: 133-139.

${ }^{6}$ Shaw RS, Maynard, EP: Acute and Chronic Thrombosis of the Mesenteric Arteries Associated with Malabsorption - A Report of Two Cases Successfully Treated by Thromboendarterectomy. N Engl J Med 1958; 258: 874-878.

${ }^{7}$ Stoney RJ, Ehrenfeld WK, Wylie EJ: Revascularization methods in chronic visceral ischemia caused by atherosclerosis. Ann Surg 1977; 186(4): 468-476.

${ }^{8}$ Kieffer E: Surgical exposure of visceral arteries. Annales de Chirurgie 2004; 129(1): 46-51.

${ }^{9}$ Fukuda W, Fukuda I, Murakami T, Saito Y, Taniguchi SM, Minakawa M: Reimplantation of a Stenotic Inferior Mesenteric Artery for Chronic Visceral Artery Occlusion after Failed Bypass to the Superior Mesenteric Artery. Ann Vasc Dis 2019; 12(4): 559-561.

10 van Petersen AS, Vriens BH, Huisman AB, Kolkman JJ, Geelkerken RH: Retroperitoneal endoscopic release in the management of celiac artery compression syndrome. J Vasc Surg 2009; 50: 140-147.

11 Stoney RJ, Wylie EJ: Surgical management of arterial lesions of the thoracoabdominal aorta. Am J Surg 1973; 126(2): 157-164.

${ }^{12}$ Hollier LH, Bernatz PE, Pairolero PC, Payne WS, Osmundson PJ: Surgical management of chronic intestinal ischemia: a reappraisal. Surgery 1981; 90(6): 940-946.

${ }^{13}$ Rapp JH, Reilly LM, Qvarfordt PG, Goldstone J, Ehrenfeld WK, Stoney RJ: Durability of endarterectomy and antegrade grafts in the treatment of chronic visceral ischemia. J Vasc Surg 1986; 3(5): 799-806.

${ }^{14}$ Cunningham CG, Reilly LM, Rapp JH, Schneider PA, Stoney RJ: Chronic visceral ischemia. Ann Surg 1991; 214: 276-287.

15 Atkins MD, Kwolek CJ, LaMuraglia GM, Brewster DC, Chung TK, Cambria RP: Surgical revascularization versus endovascular therapy for chronic mesenteric ischemia: a comparative experience. J Vasc Surg 2007; 45(6): 1162-1171. 
${ }^{16}$ Oderich GS, Malgor RD, Ricotta JJ: Open and endovascular revascularization for chronic mesenteric ischemia: tabular review of the literature. Ann Vasc Surg 2009; 23: 700-712.

${ }^{17}$ Kölbel T, Wipper S, Diener H, Debus ES: Endovaskuläre Therapie der chronisch mesenterialen Ischämie. Der Chirurg 2011; 82: 880-886.

${ }^{18}$ Aburahma AF, Campbell JE, Stone PA, Hass SM, Mousa AY, Srivastava M, Nanjundappa A, Dean LS, Keiffer T: Perioperative and late clinical outcomes of percutaneous transluminal stentings of the celiac and superior mesen- teric arteries over the past decade. J Vasc Surg. 2013; 57(4): 1052-1061.

${ }^{19}$ Acar T, Cakir V, Acar N, Atahan K, Haciyanl M: Chronic visceral ischemia: An unusual cause of abdominal pain. Turk J Surg. 2018; 34(2): 158-161.

${ }^{20}$ Menges A-L, Reutersberg B, Busch A, Salvermoser $M$, Feith M, Trenner M, Kallmayer M, Zimmermann A, Eckstein $\mathrm{H}-\mathrm{H}$ : Early and Midterm Outcomes of Open and Endovascular Revascularization of Chronic Mesenteric Ischemia. World J Surg 2020; 44(8): 2804-2812.

A cikk a Creative Commons Attribution 4.0 International License (https://creativecommons.org/licenses/by/4.0/) feltételei szerint publikált Open Access közlemény, melynek szellemében a cikk bármilyen médiumban szabadon felhasználható, megosztható és újraközölhetö, feltéve, hogy az eredeti szerző és a közlés helye, illetve a CC License linkje és az esetlegesen végrehajtott módosítások feltüntetésre kerülnek. (SID_1) 